\title{
Irrelevance of anti-nAChR cytoplasmic loop antibody in the degree of myasthenia gravis
}

\author{
YE LIN $^{1 *}$, CHEN SONG $^{1,2 *}$, JIANG XU ${ }^{1}$, YONGXIANG YANG ${ }^{1}$, \\ HANG QIN $^{1}$, CONG ZHAO ${ }^{1}$, JIAJI LIN ${ }^{1}$, RUI LIU ${ }^{1}$ and ZHUYI LI ${ }^{1}$ \\ ${ }^{1}$ Department of Neurology, Tangdu Hospital, The Fourth Military Medical University, Xi'an, Shaanxi 710038; \\ ${ }^{2}$ Department of Neurology, Air Force General Hospital, Beijing 100142, P.R. China
}

Received July 17, 2016; Accepted July 10, 2017

DOI: $10.3892 /$ ijmm.2017.3074

\begin{abstract}
Anti-nicotinic acetylcholine receptor (nAChR) antibody in myasthenia gravis (MG) usually refers to that against the extracellular domain (ECD) of nAChR. However, growing evidence has indicated that there also exists the $\mathrm{nAChR}$ antibody against the nAChR cytoplasmic loop (CL) in patients with MG. Some studies have demonstrated that the anti-CL antibody may play a protective role in animal models of experimental autoimmune MG. However, to date, limited or no information is available as to whether anti-CL antibody plays a beneficial role in patients with MG. In this, we examined the levels of anti-CL and anti-ECD antibodies in the sera of 76 patients with MG from the MG sample bank of our department, including 29 generalized MG (gMG) and 47 ocular MG (OMG) cases, as well as 40 healthy controls by radioimmunoassay. We also analyzed the correlation between anti-CL antibody levels and the degree of severity in patients with MG. Our results revealed that among the 76 patients with MG, 61 serum samples $(80.3 \%)$ were positive for anti-ECD nAChR antibody, among which $38(38 / 61,62.3 \%)$ were positive for anti-CL antibody. The levels of anti-ECD antibodies in $\mathrm{gMG}$ were higher than those
\end{abstract}

Correspondence to: Dr Zhuyi Li, Department of Neurology, Tangdu Hospital, The Fourth Military Medical University, No. 1 Xinsi Road, Xi'an, Shaanxi 710038, P.R. China

E-mail: lizhuyi@fmmu.edu.cn

*Contributed equally

Abbreviations: $\alpha$-BTX, $\alpha$-bungarotoxin; BCR, B-cell antigen receptor; BME, $\beta$-mercaptoethanol; $\mathrm{CL}$, cytoplasmic loop; EAMG, experimental autoimmune myasthenia gravis; ECD, extracellular domain; EOMG, early-onset myasthenia gravis; gMG, generalized myasthenia gravis; IPTG, isopropyl $\beta$-D-1-thiogalactopyranoside; IRB, institutional review board; LOMG, late-onset myasthenia gravis; MG, myasthenia gravis; MoAb, monoclonal antibody; $\mathrm{nAChR}$, the nicotinic acetylcholine receptor; OMG, ocular myasthenia gravis; $\mathrm{SD}$, standard deviation

Key words: myasthenia gravis, nicotinic acetylcholine receptor, autoantibody, cytoplasmic loop, extracellular domain, radioimmunoassay in OMG; however, the levels of anti-CL antibodies in $\mathrm{gMG}$ were comparable with those in OMG. No clear correlation was observed between the anti-ECD antibody levels and those of anti-CL antibody. Taken together, our findings provide the first clinical evidence of the possibly different role of anti-CL antibody in patients with MG compared to its role in animal models of MG. Anti-CL antibody may not exert a beneficial effect in patients with MG, but may play an as yet udetermined role in the development of $\mathrm{MG}$.

\section{Introduction}

Myasthenia gravis (MG) is a typical autoimmune disease caused by antibodies against the muscle type nicotinic acetylcholine receptor ( $\mathrm{nAChR}$ ) of the neuromuscular junction. Anti-nAChR antibodies reduce the number of effective $n A C h R s$ at the endplate, causing the failure of synaptic electrical-chemical coupling, resulting in muscle weakness and fatigability $(1,2)$. Anti-nAChR antibodies are detectable in approximately $90 \%$ of myasthenic patient sera (3).

nAChR, from fish electric organs and vertebrate skeletal muscles, is a transmembrane glycoprotein composed of 5 homologous subunits organized into a cation channel in the order of $\alpha 1 \gamma \alpha 1 \delta \beta 1$ in denervated skeletal muscle, and $\alpha 1 \varepsilon \alpha 1 \delta \beta 1$ in innervated skeletal muscle (4). Each subunit in nAChR consists of 2 parts: the extracellular domain (ECD) and the cytoplasmic loop (CL). Agonists, such as acetylcholine and competitive antagonists, such as $\alpha$-bungarotoxin ( $\alpha$-BTX) (5), bind to the two $\alpha$ subunits and regulate the ion channel. Anti-nAChR antibodies do not bind to the Ach binding site of $\mathrm{nAChR}$, and antibody-nAChR complexes extracted from muscle do bind ${ }^{125} \mathrm{I} \alpha$-BTX. Therefore, the concentration of anti-nAChR antibodies in sera can be determined in terms of the ${ }^{125} \mathrm{I} \alpha$-BTX-binding site (6).

In the sera from patietns with MG, most anti-nAChR antibodies bind to a small region on the extracellular side of the $\alpha 1$ subunit, the main immunogenic region (MIR) (7-9). Most of the known anti-nAChR antibodies recognize the extracellular side of $\mathrm{nAChR}$ (10). However, a growing body of evidence has indicated that anti-nAChR CL antibodies also exist in the sera of patients with MG (11-13). It has been reported that approximately $17 \%$ of patients with MG are anti-CL antibodypositive (14). At present, relatively little is known regarding the 
association between anti-CL antibodies and the clinical profile of MG.

Recently, several studies have demonstrated that anti-CL antibody may play a protective role in animal models of experimental autoimmune MG (EAMG), in which they discovered a novel approach to the specific immunosuppression of EAMG with a therapeutic vaccine consisting of bacterially-expressed human $\mathrm{nAChR} C \mathrm{~L}$, which has the potential to specifically suppress MG without the danger of causing exacerbation $(11-13,15)$. However, to date, information about the constitutive effects of anti-CL antibody on the process of MG and its relevance to the degree of MG is lacking. In our retrospective study, we measured the levels of anti-CL antibody in the serum samples of 76 patients with MG, and analyzed its association with the clinical profile and anti-ECD muscle nAChR titers.

\section{Materials and methods}

Human subjects. The sera from 76 patients with MG were collected from the MG sample bank of the Department of Neurology, Tangdu Hospital, Xi'an, China. All samples in the MG sample bank were diagnosed according to the diagnostic criteria. The following criteria were used to diagnose MG (16,17): i) acquired weakness of skeletal muscles, including cranial muscles; ii) fluctuation in muscle strength; iii) $10 \%$ decrease in compound muscle action potential amplitude in response to stimulation at $3-5 \mathrm{~Hz}$ and increased jitter on single-fiber electromyography; and iv) positive response to a cholinesterase inhibitor. Exclusion criteria were pregnancy. A total of 40 healthy subjects were recruited as the controls and were matched with the patients with MG in age, sex and demography. According to the principles expressed in the Helsinki Declaration and to the ethics committee-approved protocols, all subjects provided written and signed informed consent prior to enrollment. Blood sample collections from human subjects for detailed immunological assessments were approved by the Ethics Committee of the Fourth Military Medical University. All patients and healthy controls provided written informed consent.

Preparation of human muscle native $n A C h R$. Human skeletal muscle was obtained from the amputated leg of a diabetic patient treated for gangrene as the $\mathrm{nAChR}$ source. We followed the protocols described in the studies by Lindstrom et al (6) and Chang et al (18) and made necessary changes. The muscle was chopped into small sections of 10-15 g, flash-frozen in liquid nitrogen and stored at $-80^{\circ} \mathrm{C}$. Muscle was homogenized with a pre-chilled electrical blender for $1-2 \mathrm{~min}$ a $4^{\circ} \mathrm{C}$ in $300 \mathrm{ml}$ of $0.1 \mathrm{M} \mathrm{NaCl}, 0.01 \mathrm{M}$ phosphate buffer (pH 7.0). Following centrifugation at $9 \times 10^{3} \mathrm{rpm}$ for $20 \mathrm{~min}$, the supernatant was discarded. Homogenization and centrifugation were repeated with the pellet. The pellets were extracted in $160 \mathrm{ml}$ $2 \%$ Triton $\mathrm{X}-100,0,1 \mathrm{M} \mathrm{NaCl}, 20 \mathrm{mM}$ EDTA, $0.01 \mathrm{M}$ phosphate buffer ( $\mathrm{pH} 7.0$ ), $0.01 \mathrm{M} \mathrm{NaN}_{3}$ by homogenizing for $20 \mathrm{sec}$, followed by gentle shaking for $1 \mathrm{~h}$ at $4^{\circ} \mathrm{C}$. Following centrifugation at $10^{5} \mathrm{~g} / 4^{\circ} \mathrm{C}$ for $30 \mathrm{~min}$, the resulting supernatant was suctioned using a syringe, pooled, glycerol was added to $10 \%$, mixed well, and stored as $1 \mathrm{ml}$ aliquot at $-80^{\circ} \mathrm{C}$.
Preparation of recombinant human muscle $n A C h R C L$

Plasmid and bacterial strain. The plasmid vector $\mathrm{pET} 16 \mathrm{~b}$ and the prokaryotic expression host strain E. coli BL21 (DE3) were purchased from Novagen, Darmstadt, Germany.

Human muscle $n A C h R$ CL expression vector construction. DNA sequences encoding the CL of the human muscle $\mathrm{nAChR}$ subunits, $\alpha 1$ (residues 301-374), $\beta 1$ (residues 312-412), and $\delta$ (residues 315-416), were codon-optimized to E. Coli preferred codons and synthesized (Genscript Co., Nanjing, China). Wild-type CL from human muscle $\mathrm{nAChR} \alpha 1$ subunits lacked tyrosine residue, the key amino acid for iodination labeling. Therefore, 2 additional tyrosine residues were incorporated into the C-terminal of AChR $\alpha 1 \mathrm{CL}$ by PCR to generate the coding sequence. For the wild-type $\beta 1$ and $\delta$ subunits, which already contain the tyrosine residues, there was no need to change the synthesized coding sequences. These sequences were inserted into the NdeI and BamHI sites of pET16b (Novagen), and transformed into expression host BL21 (DE3) (Novagen). Recombinant clones were checked for insertion by restriction digestion and sequencing (Genscript Co.).

Expression and purification of proteins corresponding to the $n A C h R$ CL. Recombinant $\mathrm{nAChR} \mathrm{CL}$ was generated from the BL21 (DE3) cells harboring the expression plasmids at an OD600 of 4.0 using a homemade fermentor. This was followed by induction with $1 \mathrm{mM}$ isopropyl $\beta$-D-1thiogalactopyranoside (IPTG) for $4 \mathrm{~h}$ at $37^{\circ} \mathrm{C}$. The cell pellets were collected by centrifugation. For extraction of recombinant proteins, cell pellets were solubilized in $50 \mathrm{mM}$ phosphate buffer ( $\mathrm{pH}$ 8.0), $6 \mathrm{M}$ guanidine hydrochloride, $5 \mathrm{mM}$ imidazole, sheared with an electric blender to reduce the stickiness of the solution and centrifuged at $28,000 \mathrm{x} \mathrm{g}$ at $4^{\circ} \mathrm{C}$ for $30 \mathrm{~min}$. The supernatant was then passed through a 5-ml Histrap FF column (GE Healthcare, Piscataway, NJ, USA). Bound protein was eluted by $50 \mathrm{mM}$ phosphate buffer ( $\mathrm{pH} \mathrm{8.0)}$, $6 \mathrm{M}$ guanidine hydrochloride, $500 \mathrm{mM}$ imidazole. Eluted fractions containing protein peaks were pooled, dialyzed against $0.1 \%$ SDS, $10 \mathrm{mM}$ EDTA, and then loaded to several preparative SDS-PAGE gels. Protein bands were visualized by staining with $0.1 \mathrm{M} \mathrm{CuSO}_{4}$ solution and the band corresponding to the recombinant CL were excised. Proteins within the bands were electroeluted, dialyzed to remove residue $\mathrm{Cu}^{2+}$ ion, concentrated by ultrafiltration (Amicon Ultra $3 \mathrm{~K}$ filters) and stored at $-20^{\circ} \mathrm{C}$.

Iodination labeling of $\alpha-B T X$ and recombinant $n A C h R C L$. The recombinant $\mathrm{nAChR} C \mathrm{~L}$ proteins and $\alpha$-BTX were labeled with ${ }^{125} \mathrm{I}$ using the Chloramine $\mathrm{T}$ method as previously described by Lindstrom et al (9) and Greenwood et al (19). Briefly, $2 \mu \mathrm{Ci}$ of ${ }^{125} \mathrm{I}$ (Carrier free, Chengdu Gaotong Isotope Co., Ltd., Chengdu, China) was mixed with $12 \mu \mathrm{l}$ of $0.5 \mathrm{M}$ sodium phosphate buffer (pH 7.0) and $70 \mu \mathrm{g}$ (approximately $7 \mathrm{nmol}$ ) of recombinant $\mathrm{nAChR}$ CL protein or $\alpha$-BTX, and then mixed with $2 \mu \mathrm{l}$ of $1.6 \mathrm{M}$ chloramine $\mathrm{T}$. The mixture was then incubated on ice for $25 \mathrm{~min}$ with occasional shaking and then loaded to a PD-10 Desalting column (GE Healthcare). Protein was eluted using phosphate sodium buffer containing $0.1 \%$ SDS for recombinant $\mathrm{nAChR}$ CL or phosphate sodium buffer for $\alpha$-BTX. Fractions of $0.3 \mathrm{ml}$ were collected and monitored for radioactivity. Fractions containing radioactivity were pooled and the final volume was adjusted with phosphate buffer saline to yield a protein concentration of $2 \times 10^{-6} \mathrm{M}$. 
Radioimmunoassay of anti-native $n A C h R$ and anti-CL antibodies from the sera of patients with $M G$. Serum anti-nAChR antibodies were measured using radioimmunoprecipitation (20) by ${ }^{125} \mathrm{I} \alpha-\mathrm{BTX}$-labeled native $\mathrm{nAChR},{ }^{125} \mathrm{I}$-labeled nAChR $\alpha 1-\mathrm{CL}$, ${ }^{125}$ I-labeled nAChR $\beta 1-C L$, and ${ }^{125}$ I-labeled nAChR $\delta$-CL. For the measurement of antibodies against nAChR-CL, $500 \mu$ l of diluted ${ }^{125}$ I-labeld $\mathrm{nAChR}$ CL protein (final concentration, approximately $10^{-9} \mathrm{M}$ ) in $0.5 \%$ Triton X-100,0.005\% SDS, were incubated with $10 \mu \mathrm{l}$ of MG patient serum, followed by the addition of $10 \mu \mathrm{l}$ of rabbit anti-human antibody for $2 \mathrm{~h}$. For the measurement of antibodies against native human $\mathrm{nAChR},{ }^{125} \mathrm{I}$-labeled- $\alpha$-BTX was mixed with $1 \mathrm{ml}$ of human skeletal muscle extract to a final concentration of $10^{-9} \mathrm{M}$, followed by the addition of $10 \mu \mathrm{l}$ of rabbit anti-human antibody for $2 \mathrm{~h}$. The immune complex was precipitated by centrifugation at $13,000 \mathrm{rpm} / 4^{\circ} \mathrm{C} / 5 \mathrm{~min}$, and the pellets washed twice with PBS (pH7.2) containing $0.5 \%$ Triton $\mathrm{X}-100$. The radioactivity was measured using a $\gamma$-counter (CNNC Xi'an Nuclear Instrument Factory, Xi'an, China). Background radioactivity was measured without patient serum.

Statistical analysis. The antibody concentrations of anti-native $\mathrm{nAChR}$ and anti-CL are expressed in $\mathrm{nM}$. The data were analyzed using SPSS 17.0 software. Continuous variables are listed as the means \pm standard deviation (SD) and were analyzed using the Student's t-test. The differences in sex, MG type according to onset age, MG type and onset MG type were analyzed using Chi-square tests, and the analysis of antibody of ECD and CL were tested by linear regression analysis. A two-tailed P-value of $<0.05$ was considered to indicate a statistically significant difference.

\section{Results}

Expression and purification of three CLs from human muscle $n A C h R$ in the $\alpha 1, \beta 1$ and $\delta$ subunits. We generated 3 target proteins with a gradient of molecular masses at approximately $15 \mathrm{kDa}$ (Fig. 1A). We optimized the purification of CLs from $\mathrm{nAChR}$ proteins with recombinant protein fractions (Fig. 1B).

Patient data. A total of 76 patients were clinically diagnosed with MG. The patient characteristics are shown in Table I and summarized in Table II. There were 46 (60.5\%) males and $30(39.5 \%)$ females. The median age at diagnosis was 45 years (range, 2-79 years). A total of 11 patients (14.5\%) had thymoma; 2 patients $(2.6 \%)$ had hyperthyroidism and 2 patients $(2.6 \%)$ had rheumatoid arthritis. In the present study, 29 patients $(38.2 \%)$ were clinically classified as ocular MG (OMG) and 47 patients $(61.8 \%)$ were classified as generalized MG (gMG). In total, 42 patients $(55.3 \%)$ were diagnosed with OMG initially and $13(30.1 \%)$ of these 42 patients then developed gMG. A total of $34(44.8 \%)$ patients were initially diagnosed with gMG.

Anti-CL antibody levels in patients with different types of $M G$. In total, $61(80.3 \%)$ were native $\mathrm{nAChR}$ antibody-positive. In addition, 29 (38.2\%), 27 (35.5\%) and 25 samples (32.9\%) were positive for antibodies to $\alpha 1 \mathrm{CL}, \beta 1 \mathrm{CL}$ and $\delta \mathrm{CL}$, respectively. The results revealed that $50 \%$ (38 of the patients with MG) had antibodies to at least one of the three CL domains of nAChR (Table II). We found that $30.3 \%$ (23 of the patients with MG) had antibodies to more than one of the three CL domains
A B

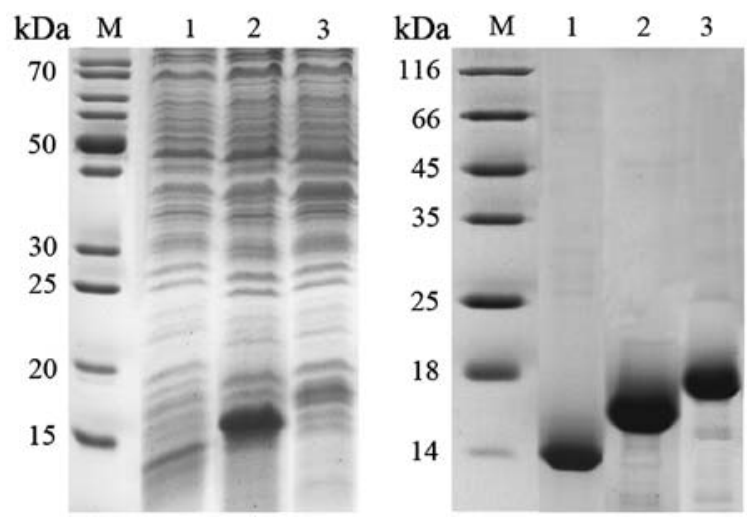

Figure 1. Expression and purification of CLs of $\alpha 1, \beta 1$ and $\delta$ subunits in $n A C h R$. (A) SDS-PAGE of recombinant CLs of $\alpha 1, \beta 1$ and $\delta$ subunits in $\mathrm{nAChR}$ before purification. Lane M, marker; lane 1, CLs of $\alpha 1$ subunit; lane 2, CLs of $\beta 1$ subunit; lane 3, CLs of $\delta$ subunit. (B) SDS-PAGE of recombinant CLs of $\alpha 1, \beta 1$ and $\delta$ subunit in $\mathrm{nAChR}$ after purification. Lane M, marker; lane 1, CLs of $\alpha 1$ subunit; lane 2, CLs of $\beta 1$ subunit; lane 3, CLs of $\delta$ subunit.

of nAChR. Of these, 20 were positive for all three CL antibodies. The results also revealed that 38 (38/61, 62.3\%) were positive for anti-CL antibody among the 61 anti-ECD antibodypositive patients. These results suggested that approximately half of the patients with MG were anti-CL antibody-positive.

The levels of anti- $\alpha 1 C L$ antibodies in the patients with OMG were higher compared with those of the control subjects $(\mathrm{P}<0.01)$. The gMG rates were also significantly higher compared with the controls $(\mathrm{P}<0.001)$; however, there was no difference in these levels between the patients with OMG and gMG (Fig. 2A). The results of $\beta 1$ and $\delta$ subunits displayed a similar pattern (Fig. 2B and C). However, the levels of anti-native $\mathrm{nAChR}$ antibodies in $\mathrm{gMG}$ were higher than those in OMG (Fig. 2D). We measured absorption to the ECD of nAChR as follows: the absorption of ${ }^{125}$ I-toxin-labeled native nAChR minus the absorption of ${ }^{125}$ I-labeled CL titers. The levels of anti-ECD antibodies in $\mathrm{gMG}$ were also higher than those in OMG (Fig. 2E). Taken together, our findings indicated that anti-CL antibodies in the patients with MG were higher than those in the controls, particularly in the patients with gMG; however, the levels of anti-CL antibodies did not differ between the patients with OMG and gMG.

Association between anti-CL antibody and anti-native $n A C h R$ antibody in patients with MG. We tested sera from 76 patients with $\mathrm{MG}$ for antibodies directed against native $\mathrm{nAChR}$ and the CLs of $\mathrm{nAChR}$ by immunoprecipitation with ${ }^{125} \mathrm{I} \alpha$-BTX-labeled $\mathrm{nAChR}$ and ${ }^{125}$ I-labeled CLs. Three antibodies against CLs in the $\alpha 1, \beta 1$ and $\delta$ subunits of $\mathrm{nAChR}$ were arranged in order of the increasing concentration of anti-native nAChR antibodies (Fig. 3A). In total, 11 patients (14.5\%) had thymoma (Table II). Approximately half of these were anti-CLnegative. The other half of the patients with thymoma, even though they were anti-CL antibody-positive, the levels of anti-CL antibody were $<2 \mathrm{nM}$ (Fig. 3A).

We classified the patients with MG into 4 groups according to the concentration of anti-native $\mathrm{nAChR}$ antibody as $<0.6,0.6-6.6,6.6-66$, or $>66 \mathrm{nM}$ (Fig. 3B). We compared the positive rates of anti-CL antibodies among the 4 groups. We 
Table I. Patient characteristics.

\begin{tabular}{|c|c|c|c|c|c|c|c|c|}
\hline No. & $\begin{array}{c}\text { Age } \\
\text { (years) }\end{array}$ & Sex & $\begin{array}{l}\text { Disease duration } \\
\text { (months) }\end{array}$ & $\begin{array}{l}\text { Maximum } \\
\text { MGFA class }\end{array}$ & $\begin{array}{l}\text { Thymus } \\
\text { change }\end{array}$ & $\begin{array}{c}\text { Other autoimmune } \\
\text { disease }\end{array}$ & $\begin{array}{l}\text { AChR titer } \\
(\mathrm{nmol} / \mathrm{l})\end{array}$ & $\begin{array}{l}\text { All previous } \\
\text { therapies at } \\
\text { blood draw }\end{array}$ \\
\hline 1 & 46 & M & 9 & II & Thymoma & None & 38.08 & $\mathrm{~PB}, \mathrm{TS}$ \\
\hline 2 & 9 & M & 36 & II & None & None & 6.98 & $\mathrm{~PB}$ \\
\hline 3 & 46 & $\mathrm{M}$ & 180 & II & None & Hyperthyroidism & 1.03 & $\mathrm{~PB}$ \\
\hline 4 & 17 & $\mathrm{M}$ & 0.3 & I & n.a. & None & 0.19 & None \\
\hline 5 & 13 & $\mathrm{M}$ & 120 & I & None & None & 178.04 & PB, Pred \\
\hline 6 & 35 & $\mathrm{M}$ & 84 & II & None & None & 0.17 & PB, Pred, MMF \\
\hline 7 & 12 & $\mathrm{M}$ & 1 & II & None & None & 0.56 & PB \\
\hline 8 & 38 & $\mathrm{~F}$ & 4 & II & None & None & 45.48 & PB \\
\hline 9 & 18 & $\mathrm{~F}$ & 2 & II & Thymoma & None & 166.74 & PB, Pred, TS \\
\hline 10 & 54 & $\mathrm{M}$ & 2 & II & None & None & 75.16 & $\mathrm{~PB}$ \\
\hline 11 & 22 & $\mathrm{~F}$ & 2 & I & None & None & 135.24 & None \\
\hline 12 & 31 & $\mathrm{~F}$ & 8 & II & None & None & 60.50 & PB, Pred, CYC \\
\hline 13 & 51 & F & 3 & II & None & Hypothyroidism & 33.78 & PB \\
\hline 14 & 55 & F & 2 & II & Thymoma & None & 31.48 & $\mathrm{~PB}, \mathrm{TS}$ \\
\hline 15 & 50 & M & 84 & II & None & None & 289.84 & PB, Pred \\
\hline 16 & 67 & M & 36 & II & None & None & 29.08 & PB, Pred, CYC \\
\hline 17 & 2.1 & M & 2 & I & None & None & 0.68 & PB \\
\hline 18 & 27 & $\mathrm{~F}$ & 24 & II & None & None & 26.58 & PB, Pred, AZA \\
\hline 19 & 53 & $\mathrm{~F}$ & 324 & I & None & None & 1.34 & PB, Pred, MMF \\
\hline 20 & 55 & $\mathrm{~F}$ & 6 & II & None & RA & 120.24 & $\mathrm{~PB}$ \\
\hline 21 & 60 & $\mathrm{M}$ & 6 & II & None & None & 115.70 & n.a. \\
\hline 22 & 54 & $\mathrm{M}$ & 2 & II & Thymoma & None & 8.18 & PB \\
\hline 23 & 23 & $\mathrm{~F}$ & 12 & II & None & None & 378.14 & PB, Pred \\
\hline 24 & 55 & $\mathrm{M}$ & 2 & I & None & None & 1.19 & None \\
\hline 25 & 66 & $\mathrm{~F}$ & 8 & II & Thymoma & None & 1.44 & $\mathrm{~PB}, \mathrm{TS}$ \\
\hline 26 & 53 & $\mathrm{~F}$ & 36 & II & None & RA & 125.24 & PB, Pred \\
\hline 27 & 47 & $\mathrm{M}$ & 3 & I & None & None & 323.24 & $\mathrm{~PB}$ \\
\hline 28 & 57 & $\mathrm{M}$ & 24 & I & None & None & 324.64 & PB \\
\hline 29 & 51 & $\mathrm{M}$ & 3 & II & None & None & 4.35 & n.a. \\
\hline 30 & 30 & $\mathrm{M}$ & 11 & I & None & None & 0.90 & n.a. \\
\hline 31 & 51 & $\mathrm{M}$ & 0.6 & I & n.a. & None & 87.63 & PB \\
\hline 32 & 39 & $\mathrm{~F}$ & 360 & II & None & None & 21.18 & PB \\
\hline 33 & 67 & $\mathrm{M}$ & 72 & II & None & None & 80.96 & n.a. \\
\hline 34 & 46 & $\mathrm{~F}$ & 3 & II & None & None & 1.76 & PB \\
\hline 35 & 26 & $\mathrm{~F}$ & 12 & II & None & None & 506.84 & $\mathrm{~PB}$ \\
\hline 36 & 23 & M & 36 & I & None & None & 0.47 & PB, Pred, AZA \\
\hline 37 & 16 & $\mathrm{M}$ & 2 & I & None & None & 1.70 & None \\
\hline 38 & 50 & $\mathrm{~F}$ & 0.3 & II & n.a. & None & 23.98 & None \\
\hline 39 & 13 & $\mathrm{~F}$ & 60 & II & None & None & 91.76 & PB, Pred \\
\hline 40 & 71 & $\mathrm{M}$ & 0.6 & II & n.a. & None & 201.64 & None \\
\hline 41 & 39 & $\mathrm{M}$ & 3 & II & None & None & 54.10 & None \\
\hline 42 & 13 & $\mathrm{M}$ & 132 & I & None & None & 68.02 & PB, Pred, AZA \\
\hline 43 & 17 & M & 36 & II & None & None & 16.28 & $\mathrm{~PB}$ \\
\hline 44 & 32 & $\mathrm{~F}$ & 180 & I & None & None & 105.07 & PB, CYC, IVIg \\
\hline 45 & 50 & $\mathrm{M}$ & 24 & II & None & None & 51.94 & PB \\
\hline 46 & 61 & $\mathrm{M}$ & 480 & III & None & None & 2.01 & PB, Pred, CYC \\
\hline 47 & 61 & $\mathrm{~F}$ & 84 & II & None & None & 11.38 & n.a. \\
\hline 48 & 47 & $\mathrm{M}$ & 60 & II & Thymoma & None & 61.57 & $\mathrm{~PB}, \mathrm{TS}$ \\
\hline 49 & 9 & $\mathrm{M}$ & 8 & II & Thymoma & None & 0.44 & $\mathrm{~PB}, \mathrm{TS}$ \\
\hline 50 & 28 & M & 264 & II & None & None & 145.44 & $\begin{array}{l}\text { PB, Pred, AZA, } \\
\text { IVIg }\end{array}$ \\
\hline 51 & 47 & M & 60 & III & Thymoma & None & 483.84 & $\begin{array}{l}\text { PB, Pred, AZA, } \\
\text { IVIg, TS }\end{array}$ \\
\hline
\end{tabular}


Table I. Continued.

\begin{tabular}{|c|c|c|c|c|c|c|c|c|}
\hline No. & $\begin{array}{c}\text { Age } \\
\text { (years) }\end{array}$ & Sex & $\begin{array}{l}\text { Disease duration } \\
\text { (months) }\end{array}$ & $\begin{array}{l}\text { Maximum } \\
\text { MGFA class }\end{array}$ & $\begin{array}{l}\text { Thymus } \\
\text { change }\end{array}$ & $\begin{array}{l}\text { Other autoimmune } \\
\text { disease }\end{array}$ & $\begin{array}{l}\text { AChR titer } \\
(\mathrm{nmol} / \mathrm{l})\end{array}$ & $\begin{array}{l}\text { All previous } \\
\text { therapies at } \\
\text { blood draw }\end{array}$ \\
\hline 52 & 55 & M & 4 & II & None & None & 0.58 & None \\
\hline 53 & 55 & M & 10 & I & None & None & 397.14 & None \\
\hline 54 & 3 & M & 0.6 & I & n.a. & None & 0.50 & None \\
\hline 55 & 65 & M & 0.3 & II & None & None & 0.52 & None \\
\hline 56 & 64 & M & 2 & II & None & None & 359.54 & None \\
\hline 57 & 34 & $\mathrm{~F}$ & 120 & II & Thymoma & None & 4.33 & $\begin{array}{l}\text { PB, Pred, AZA, } \\
\text { TS }\end{array}$ \\
\hline 58 & 59 & $\mathrm{~F}$ & 9 & I & None & None & 0.07 & PB \\
\hline 59 & 50 & M & 4 & II & Thymoma & None & 9.58 & $\mathrm{~PB}, \mathrm{TS}$ \\
\hline 60 & 17 & M & 24 & I & None & None & 458.84 & PB, Pred \\
\hline 61 & 24 & $\mathrm{~F}$ & 8 & II & None & None & 57.50 & PB \\
\hline 62 & 24 & $\mathrm{~F}$ & 8 & II & None & None & 156.24 & PB \\
\hline 63 & 79 & $\mathrm{~F}$ & 24 & II & Thymoma & None & 437.64 & $\begin{array}{l}\text { PB, Pred, AZA, } \\
\text { IVIg, TS }\end{array}$ \\
\hline 64 & 45 & M & 60 & I & Thymoma & None & 226.94 & PB, Pred, TS \\
\hline 65 & 24 & $\mathrm{~F}$ & 8 & II & None & None & 42.98 & $\mathrm{~PB}$ \\
\hline 66 & 51 & $\mathrm{~F}$ & 24 & II & None & None & 18.28 & None \\
\hline 67 & 24 & $\mathrm{~F}$ & 0.1 & II & None & None & 189.64 & None \\
\hline 68 & 10 & $\mathrm{~F}$ & 36 & II & None & None & 6.33 & PB, Pred, AZA \\
\hline 69 & 2.6 & M & 1 & I & None & None & 13.48 & PB \\
\hline 70 & 31 & M & 156 & I & None & None & 39.98 & n.a. \\
\hline 71 & 11 & M & 96 & I & None & None & 35.98 & PB \\
\hline 72 & 27 & M & 1 & I & None & None & 214.04 & None \\
\hline 73 & 27 & $\mathrm{~F}$ & 0.6 & II & n.a. & None & 3.27 & PB, Pred, AZA \\
\hline 74 & 51 & $\mathrm{~F}$ & 10 & II & None & None & 3.66 & PB \\
\hline 75 & 67 & M & 12 & II & None & None & 7.35 & PB, Pred, CYC \\
\hline 76 & 42 & $\mathrm{~F}$ & 24 & I & None & None & 48.78 & None \\
\hline
\end{tabular}

M, male; F, female; n.a., not available; RA, rheumatoid arthritis; PB, pyridostigmine bromide; TS, thymussectomy; Pred, prednisone/prednisdone; MMF, mycophenolate; CYC, cyclophosphamide; AZA, azathioprine; IVIg, intravenous immunoglobulin.

found that no patients were anti-CL antibody-positive in the sera titer $<0.6 \mathrm{nM}$ group. In the group with sera titers between 0.6 and $6.6 \mathrm{nM}$, anti-CL positivity was $20 \%$. The anti-CL antibody positive rates in the sera titer group between 6.6 and $66 \mathrm{nM}$ group was $50 \%$, and $40 \%$ in the $>66 \mathrm{nM}$ group. We randomly selected samples from the 4 groups to further analyze the consistency in the 3 anti-CL antibodies. We found that the 3 anti-CL antibodies exhibited similar results, particularly in the low titer of anti-CL antibodies in patient nos. 6 and 52 (Fig. 3C).

We examined the correlation of antibodies directed against the CLs of $\mathrm{nAChR}$ and native $\mathrm{nAChR}$. The results revealed no correlation between antibodies to CLs and antibodies to native $\mathrm{nAChR}$ (Fig. 4A-C). Likewise, antibodies to CLs of $n A C h R$ were not associated with antibodies to ECD of nAChR (Fig. 4D-F).

No relevance of anti-CL antibody with sex, age and $M G$ type in patients with $M G$. We assumed the sample was anti-CL antibody-positive if any of the 3 anti-CL antibody levels (from subunits $\alpha 1, \beta 1$ and $\delta$ ) was $>0.6 \mathrm{nM}$ (21). Out of the 29 patients with OMG, 14 (48\%) were anti-CL-positive; of the 47 patients with gMG, 24 (51\%) were anti-CL-positive. However, there was no significant difference in anti-CL positivity between the patients with OMG and gMG. According to the age at onset, MG was classified into early-onset MG (EOMG) and late-onset MG (LOMG). We found no statistically significant difference in the anti-CL antibody positivity rates between the patients with EOMG and LOMG (Table III). Apart from the frequency of positive antibody, the levels of anti-CLs, anti-native nAChR and anti-ECD antibodies were compared between sexes, the type of MG according to the onset age and the onset MG type. The results revealed no differences in the level of anti-CL antibodies between sexes, the type of MG according to the age at onset and the type of MG at onset. The results were comparable with those of the anti-native nAChR antibody and anti-ECD antibody (data not shown).

\section{Discussion}

In the present study, we successfully expressed and purified the $\alpha 1, \beta 1$ and $\delta$ subunits of CL in $\mathrm{nAChR}$, which are common in both fetal and adult $\mathrm{nAChR}$. We detected anti-CL antibodies 

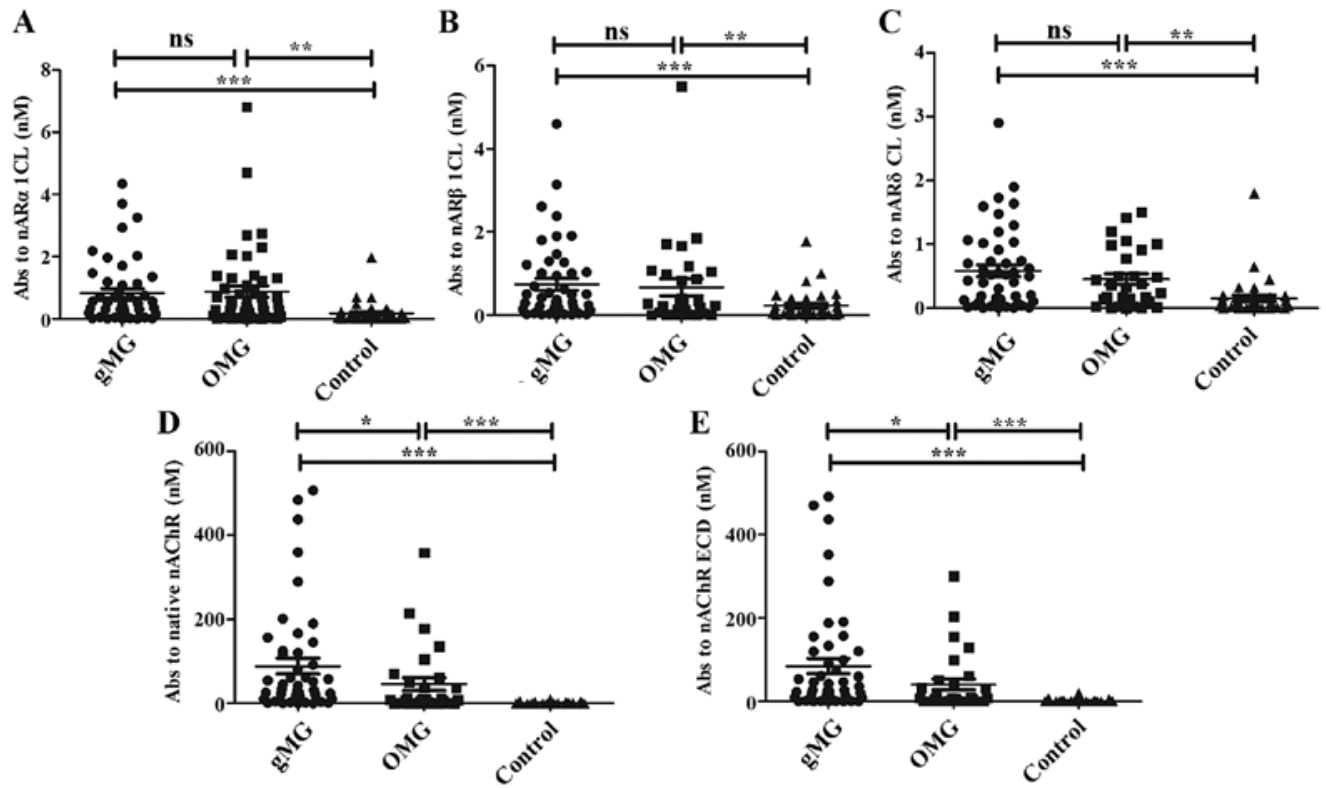

Figure 2. Levels of $n A C h R$ antibody compared between different MG types. Antibodies directed against CLs in $\alpha 1, \beta 1$ and $\delta$ subunits and against native and ECD in nAChR compared in the controls and in patients with OMG and gMG. All serum was tested 3 times; each data point represents the mean of individual subjects. Horizontal lines represent the group median. ns, no significance $(\mathrm{P}>0.05) ;{ }^{*} \mathrm{P}<0.05 ;{ }^{* *} \mathrm{P}<0.01 ;{ }^{* * * *} \mathrm{P}<0.001$. nAChR, nicotinic acetylcholine receptor; $\mathrm{MG}$, myasthenia gravis; CL, cytoplasmic loop; ECD, extracellular domain; OMG, ocular myasthenia gravis; gMG, generalized myasthenia gravis.
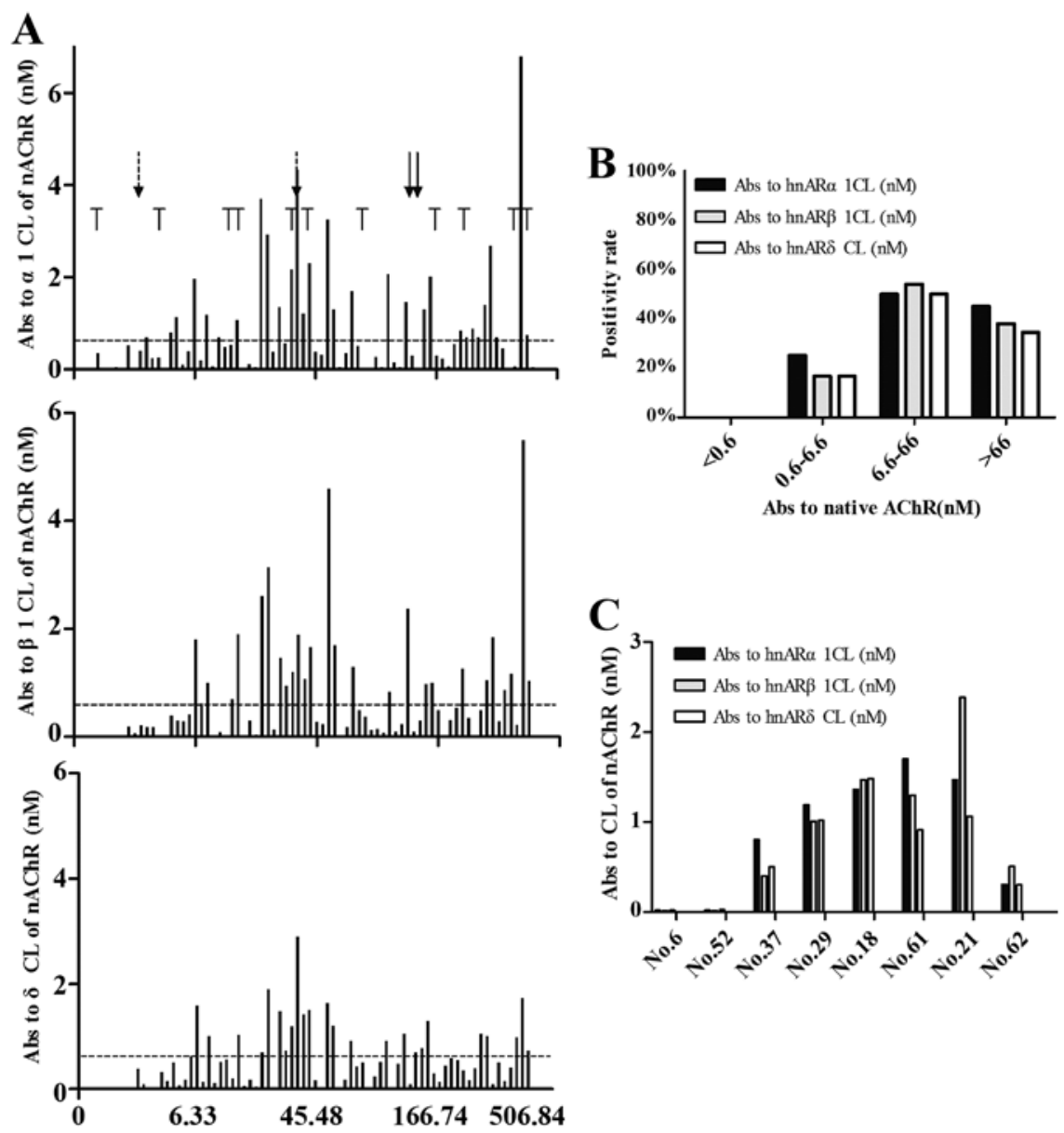

Figure 3. Radioimmunoassay detected antibodies directed against $3 \mathrm{nAChR}$ subunits $(\alpha, \beta, \delta) \mathrm{CL}$ from sera of patients with MG. ${ }^{125} \mathrm{I}-\mathrm{labeled} \mathrm{AChR} \alpha 1 \mathrm{CL}$, ${ }^{125}$ I-labeled AChR $\beta 1 C L$ and ${ }^{125}$-labeled AChRoCL were incubated with $10 \mu \mathrm{l}$ of one of 76 MG patient sera, the Ab-bound labeled AChRCL was immunoprecipitated using rabbit anti-human immunoglobulin sera. (A) The sera are arranged in order of increasing concentration (nM); the 20th, 40th, 60th and 76th sera are indicated. The horizontal dotted lines indicate the concentration of the antibodies in sera $\geq 0.6 \mathrm{nM}$. ' $\mathrm{T}$ ' marks indicate sera from 12 patients with MG with thymoma. Arrows with solid and dashed line indicate patients with MG with hyperthyroidism and RA, respectively. (B) The positive rate of anti-CL antibodies are displayed in 4 groups according to the sera titer of anti-native $\mathrm{nAChR}$. We assume that any type of anti-CL antibody $>0.6 \mathrm{nM}$ was antibody positive. (C) We selected 8 patients randomly from the 76 patients with MG, and compared the coherence of 3 types of anti-CL antibodies. nAChR, nicotinic acetylcholine receptor; CL, cytoplasmic loop; MG, myasthenia gravis. 
Table II. Demographic and clinical characteristics of the 76 patients with MG.

\begin{tabular}{lc}
\hline Variable & $\begin{array}{c}\text { Value (no. of } \\
\text { patients, } \%)\end{array}$ \\
\hline Sex & \\
Male & $46(60.5)$ \\
Female & $30(39.5)$ \\
MG type according to age at onset & \\
EOMG & $51(67.1)$ \\
LOMG & $25(32.9)$ \\
MG type & \\
OMG & $29(38.2)$ \\
gMG & $47(61.8)$ \\
MG type at onset & \\
OMG & $42(55.3)$ \\
gMG & $34(44.8)$ \\
With thymoma & $11(14.5)$ \\
With hyperthyroidism & $2(2.6)$ \\
With RA & $2(2.6)$ \\
Native AChR Abs positivity & $61(80.3)$ \\
CL Abs positivity & $38(50.0)$ \\
$\alpha 1 C L$ Abs positivity & $29(38.2)$ \\
SCL Abs positivity & $27(35.5)$ \\
More than one CL Abs positivity & $25(32.9)$ \\
All three CL Abs positivity & $23(30.3)$ \\
& $20(26.3)$ \\
\hline
\end{tabular}

MG, myasthenia gravis; EOMG, early-onset myasthenia gravis; LOMG, late-onset myasthenia gravis; OMG, ocular myasthenia gravis; gMG, generalized myasthenia gravis; RA, rheumatoid arthritis; ECD $\mathrm{Ab}$ positive, antibodies to extracellular domain of human nicotinic acetylcholine receptor $\geq 0.6 \mathrm{nM}$; CL Ab positive, any of three kinds of antibodies against to cytoplasmic loop $\geq 0.6 \mathrm{nM} ; \alpha 1 \mathrm{CL} \mathrm{Ab}$, antibodies to cytoplasmic loop in $\alpha 1$ subunit $\geq 0.6 \mathrm{nM} ; \beta 1 \mathrm{CL} \mathrm{Ab}$, antibodies to cytoplasmic loop in $\beta 1$ subunit $\geq 0.6 \mathrm{nM} ; \delta C L \mathrm{Ab}$, antibodies to cytoplasmic loop in $\delta$ subunit $\geq 0.6 \mathrm{nM}$.

in 76 patients with MG and found that the levels of any of the 3 anti-CL antibodies were significantly higher in the patients with MG compared with the controls.

It is important to address the significance of the existence of antibodies directed against CL of $\mathrm{nAChR}$. It is important to determine whether these antibodies directed against CL of $\mathrm{nAChR}$ play a functional role in MG. Several studies have reported that anti-CL antibody of $n A C h R$ plays a protective role in the development of EAMG (11-13). For example, Luo et al demonstrated a therapeutic vaccine consisting of bacterially-expressed human muscle nAChR cytoplasmic domains for the antigen-specific immunosuppression of $\mathrm{MG}$ to be safe, robust and long-lasting (15). Several studies have confirmed the existence of anti-CL of $\mathrm{nAChR}$ antibodies in both patients with MG and EAMG (22-24). However, the mechanisms involved are still unknown. It has been suggested that $B$ cells are suppressed by the secreting antibody, supporting the inhibitory receptor Fc $\gamma$ RIIB on the surface of B cells $(25,26)$.
Table III. Clinical differences between patients who were CLAbpositive and those that were CL Ab-negative.

\begin{tabular}{llll}
\hline & \multicolumn{2}{c}{ CL Abs (n=38) } & \\
\cline { 2 - 3 } $\begin{array}{l}\text { Variable (no. of } \\
\text { patients) }\end{array}$ & Positive (\%) & Negative (\%) & P-value \\
\hline Sex & & & \\
Male (46) & $23(50)$ & $23(50)$ & 1 \\
Female (30) & $15(50)$ & $15(50)$ & \\
MG type according & & & \\
to age at onset & & & \\
EOMG (51) & $27(53)$ & $24(47)$ & 0.46 \\
LOMG (25) & $11(44)$ & $14(56)$ & \\
MG type & & & \\
OMG (29) & $14(48)$ & $15(52)$ & 0.81 \\
gMG (47) & $24(51)$ & $23(49)$ & \\
MG type at onset & & & \\
OMG (42) & $19(45)$ & $23(55)$ & 0.36 \\
gMG (34) & $19(56)$ & $15(44)$ & \\
\hline
\end{tabular}

MG, myasthenia gravis; EOMG, early-onset myasthenia gravis; LOMG, late-onset myasthenia gravis; OMG, ocular myasthenia gravis; gMG, generalized myasthenia gravis; CL $\mathrm{Ab}$, antibodies to human nicotinic acetylcholine receptor cytoplasmic loop.

It is tempting to speculate that followng the immunization of the CLs of nAChR, the levels of anti-CL antibodies increase and clinical symptoms are relieved. This may be due to the combination of the antigen-antibody complexes and inhibitory receptor Fc $\gamma$ RIIB, which strongly inhibits specific B cells that produce anti-ECD antibodies (27) in patients with MG. Based on these data, we proposed a negative feed-back theoretical model to explain how the anti-CL loop protects against EAMG in animal models (Fig. 5). In this proposed mechanism, B cells specific to the ECD of the $\alpha$ subunit capture the $\mathrm{nAChR}$, which is bound with an antibody to CL of the $\delta$ (Fig. 5A), or $\alpha$ (Fig. 5B) subunits, or the ECD of $\alpha$ subunit (Fig. 5C). The Fc portions of these antibodies bind to the Fc $\gamma$ RIIB, an inhibitory receptor on the surface of the same $B$ cell, leading to inactivation of those B cells.

However, even though the levels of anti-ECD antibody in patients with gMG were higher than those in patients with OMG, there were no differences observed in the levels of anti-CL antibodies between patients with OMG and gMG in our results. There was also no correlation between anti-CL and anti-ECD antibody. These findings suggest that anti-CL antibodies may be not beneficial antibodies in patients with MG.

In fact, EAMG differs from MG in that EAMG is triggered by immunizing animals with detergent-solubilized native nAChR, such as Triton X-100. Electron microscopy studies have indicated that these Triton X-100-solubilized nAChRs are embedded in tubular and globular structures formed by membrane lipids and detergent micelles $(28,29)$. The CLs of $\mathrm{nAChR}$ were exposed to the immunological environment rather than protected by the cellular membranes, which can mediate the immune response at the initiation of EAMG. Although 

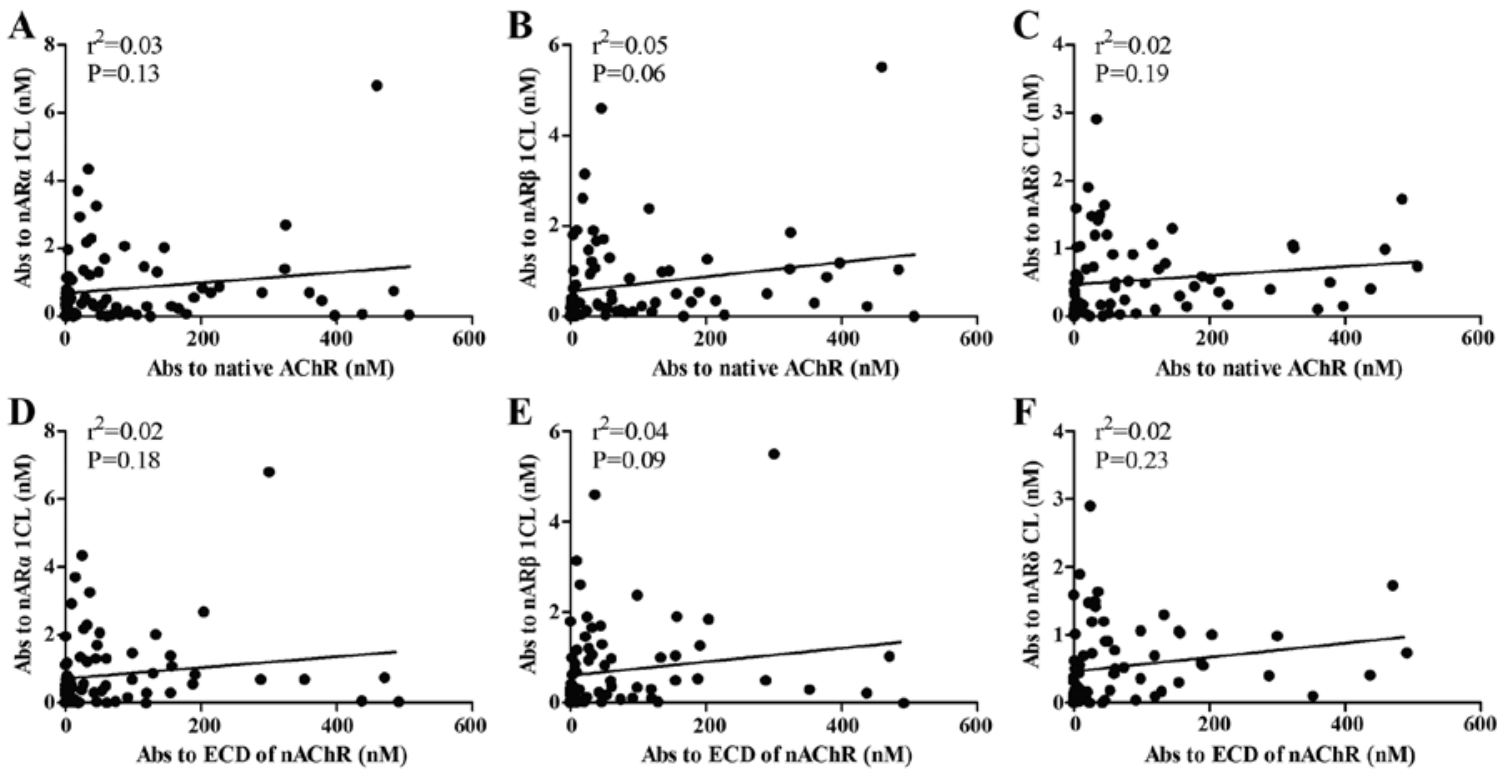

Figure 4. Correlations between anti-CL antibodies and anti-ECD antibodies. (A-C) The correlation between the concentration of antibodies to CL in $\alpha 1, \beta 1$ and $\delta$ subunit of $n A C h R(n M)$ and antibodies to native $n A C h R$. (D and E) The correlation between the concentration of antibodies to CL in $\alpha 1, \beta 1$ and $\delta$ subunit of $\mathrm{nAChR}(\mathrm{nM})$ and antibodies to ECD of nAChR. The titers of antibodies to ECD of nAChR was converted according to the absorption of ${ }^{125}$-toxin-labeled native AChR minus the adsorption of ${ }^{125}$ I-labeled CL. (A-F) Each data point represents individual subjects. The oblique line is a line with linear regression. The regression coefficient and the statistical significance are shown as $\mathrm{r}^{2}$ and P-values. CL, cytoplasmic loop; ECD, extracellular domain; nAChR, nicotinic acetylcholine receptor.

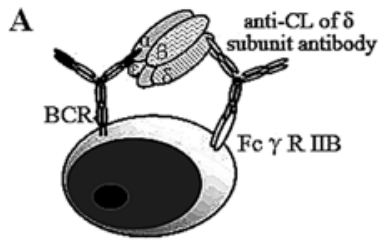

$\alpha$ subunit ECD specific B cell

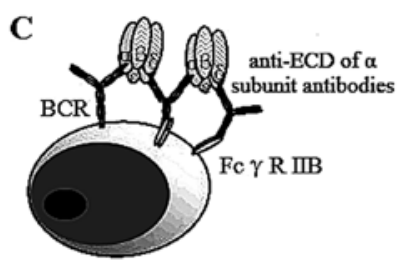

a subunit ECD specific B cell

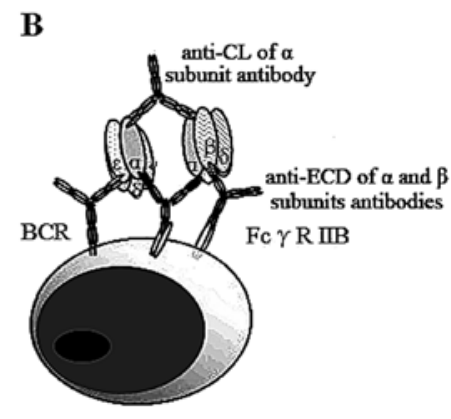

$\varepsilon$ subunit ECD specific B cell

Figure 5. Proposed mechanism of inhibition of specific B cell by anti-CL of nAChR antibody. (A) Specific B cell to ECD of $\alpha$ subunit captured an antigen of $\mathrm{nAChR}$. The antigen $\mathrm{nAChR}$ was bound with an-anti-CL of $\delta$ subunit antibody. The Fc portion of this antibody connected to the Fc $\gamma$ RIIB inhibitory receptor on $\mathrm{B}$ cell and prevented this $\mathrm{B}$ cell from producing antibodies to ECD of $\alpha$ subunit. (B) Specific B cell to ECD of $\varepsilon$ subunit captured $\mathrm{nAChR}$, which cross linked another $\mathrm{nAChR}$ by antibody to the $\mathrm{CL}$ of subunit. The corresponding antibodies to ECD of the two nAChR connected to the Fc $\gamma$ RIIB inhibitory receptor and prevented $\mathrm{B}$ cell from producing antibodies to ECD of $\varepsilon$ subunit. (C) Specific B cell to ECD of $\alpha$ subunit captured a complex of nAChR- antibody Fc portions of these antibodies in the complex connected to the Fc $\gamma$ RIIB inhibitory receptor on the $\mathrm{B}$ cell and prevented $\mathrm{B}$ cell from producing antibodies to $\mathrm{ECD}$ of $\alpha$ subunit. nAChR, nicotinic acetylcholine receptor; CL, cytoplasmic loop; ECD, extracellular domain.

we can explain the protective effect of anti-CL antibodies on EMAM using a negative feed-back theory, it does not confirm that this mechanism exists in patients with MG. This means that anti-CL antibody may not serve as a negative feed-back bridge if the CL of $n A C h R$ that triggers the autoimmune response in MG patient is not exposed to the environment.

Since there was no beneficial effect of anti-CL antibody in patients with $\mathrm{MG}$, it would be benefial to determine how anti-CL antibody could possibly occur and what the role of anti-CL antibody is in patients with MG. CLs are not exposed on the cell surface in healthy humans; thus, no anti-CL antibodies are present. In patients with MG with anti-nAChR antibody, $\mathrm{nAChR}$ is destroyed through antigen-antibody reaction. The $\mathrm{CL}$ is exposed as the $\mathrm{nAChR}$ is destroyed. Therefore, anti-CL antibodies are likely produced as a result of pathological changes. However, the function of anti-CL antibody in patients with MG warrants further investigation.

In addition, we found that approximately $50 \%$ of MG sera contained antibodies directed against the CL of nAChR. This is significantly higher than findings from earlier experiments that measured the ability of a monoclonal antibody $(\mathrm{mAb})$ to inhibit the binding of MG sera to the nAChR (30), and also measured the antibody of MG sera to inhibit the binding of a MoAb detected against the CL of the nAChR (14). Our results showed that approximately a quarter of patients with MG with thymoma were anti-CL antibody-positive. This is higher than the finding of a previous study that found that no patients with MG with thymoma were anti-CL antibodypositive (14). This can be explained by the following reasons: i) the experimental methods were different. Our radioimmunoassay was direct and more sensitive. Previous methods used competition experiments that indirectly detected antibodies, missing minor antibody populations in MG sera. Due to the specificity of the MoAb used, those experiments only detected the presence of antibodies against certain epitopes of CL of $\alpha$ and $\beta$ subunits. The detection of a narrow portion of anti-CL antibodies was widened by radioimmunoassay. ii) Patients with MG in different countries had different conditions. In our study, $14.5 \%$ of patients with MG had thymoma; however, only $5.3 \%$ had thymoma in the previous study (14). iii) Patients with 
MG may have been treated with different medicines. Drugs, such as corticosteroids and immunosuppressive agents affect the immune system, particularly the expression of antibodies.

No patients in the sera titer $<0.6 \mathrm{nM}$ group were positive for anti-CL antibodies. A higher positivity rate was concentrated in the sections of sera titer between 6.6 and $66 \mathrm{nM}$, and in sera titer $>66 \mathrm{nM}$. These results suggest that the anti-CL antibodies are prone to be distributed in MG with a higher sera titer. In 11 patients with thymoma-associated MG, 10 were anti-ECD positive, but only 4 patients were anti-CL-positive (data not shown). We thus questioned whether there was an association between these two antibodies. The number of tested thymoma sera in this study was too small to draw definitive conclusions.

It should be noted that the present study was retrospective. The majority of patients coming to our hospital had been diagnosed and treated in their local primary hospital. Thus, as a preliminary exploration, we included the ready-made sera from patients with MG. Currently, we are collecting the sera of patients with MG before and after treatment for further analysis. Our preliminary study revealed that the titers of anti-CL antibodies between patients with MG with and without immunosuppressive therapy exhibited no statistically significant difference (unpublished data). Therefore, we assumed that anti-CL antibodies may not be affected under the immunosuppressive therapy.

The limitation of the present study was that the sample size was not large enough. We aim to keep collecting the sera of patients with MG to enlarge the number of samples in future studies. Despite its preliminary character, our findings still provide the first clinical evidence that anti-CL antibodies may be not a beneficial antibody in patients with MG.

In conclusion, we found a phenomenon that there was no correlation between anti-nAChR CL and the severity of MG. Anti-CL antibody in patients with MG may not seem to be predictive of the severity of MG; however, additional studies are warranted to uncover the clinical implications of anti-CL antibody in patients with MG.

\section{Acknowledgements}

The present study was supported by grants from the National Natural Science Foundation of China (nos. 31270952 and 81202357). We would like to thank Dr Austin Cape at ASJ Editors for careful reading the manuscript and providing comments.

\section{References}

1. Lindstrom JM: Acetylcholine receptors and myasthenia. Muscle Nerve 23: 453-477, 2000.

2. Vincent A, Palace J and Hilton-Jones D: Myasthenia gravis. Lancet 357: 2122-2128, 2001

3. Huijbers MG, Lipka AF, Plomp JJ, Niks EH, van der Maarel SM and Verschuuren JJ: Pathogenic immune mechanisms at the neuromuscular synapse: The role of specific antibody-binding epitopes in myasthenia gravis. J Intern Med 275: 12-26, 2014.

4. Karlin A: Emerging structure of the nicotinic acetylcholine receptors. Nat Rev Neurosci 3: 102-114, 2002.

5. Scarselli M, Spiga O, Ciutti A, Bernini A, Bracci L, Lelli B, Lozzi L, Calamandrei D, Di Maro D, Klein S and Niccolai N: NMR structure of alpha-bungarotoxin free and bound to a mimotope of the nicotinic acetylcholine receptor. Biochemistry 41: 1457-1463, 2002.
6. Lindstrom JM, Einarson BL, Lennon VA and Seybold ME: Pathological mechanisms in experimental autoimmune myasthenia gravis. I.Immunogenicity of syngeneic muscle acetylcholine receptor and quantitative extraction of receptor and antibody-receptor complexes from muscles of rats with experimental automimmune myasthenia gravis. J Exp Med 144: 726-738, 1976.

7. Tzartos SJ, Sophianos D and Efthimiadis A: Role of the main immunogenic region of acetylcholine receptor in myasthenia gravis. An Fab monoclonal antibody protects against antigenic modulation by human sera. J Immunol 134: 2343-2349, 1985.

8. Das MK and Lindstrom J: The main immunogenic region of the nicotinic acetylcholine receptor: Interaction of monoclonal antibodies with synthetic peptides. Biochem Biophys Res Commun 165: 865-871, 1989.

9. Lindstrom J, Einarson B and Tzartos S: Production and assay of antibodies to acetylcholine receptors. Methods Enzymol 74: 432-460, 1981.

10. Gilhus NE and Verschuuren JJ: Myasthenia gravis: subgroup classification and therapeutic strategies. Lancet Neurol 14: 1023-1036, 2015.

11. Luo J and Lindstrom J: Myasthenogenicity of the main immunogenic region and endogenous muscle nicotinic acetylcholine receptors. Autoimmunity 45: 245-252, 2012.

12. Lindstrom J, Luo J and Kuryatov A: Myasthenia gravis and the tops and bottoms of AChRs: Antigenic structure of the MIR and specific immunosuppression of EAMG using AChR cytoplasmic domains. Ann N Y Acad Sci 1132: 29-41, 2008.

13. Luo J and Lindstrom J: AChR-specific immunosuppressive therapy of myasthenia gravis. Biochem Pharmacol 97: 609-619, 2015.

14. Tzartos SJ and Remoundos M: Detection of antibodies directed against the cytoplasmic region of the human acetylcholine receptor in sera from myasthenia gravis patients. Clin Exp Immunol 116: 146-152, 1999.

15. Luo J and Lindstrom J: Antigen-specific immunotherapeutic vaccine for experimental autoimmune myasthenia gravis. J Immunol 193: 5044-5055, 2014.

16. Matney SE and Huff DR: Diagnosis and treatment of myasthenia gravis. Consult Pharm 22: 239-248, 2007.

17. Jaretzki A III, Barohn RJ, Ernstoff RM, Kaminski HJ, Keesey JC, Penn AS and Sanders DB: Myasthenia gravis: recommendations for clinical research standards. Task Force of the Medical Scientific Advisory Board of the Myasthenia Gravis Foundation of America. Neurology 55: 16-23, 2000.

18. Chang HW: Purification and characterization of acetylcholine receptor-I from Electrophorus electricus. Proc Natl Acad Sci USA 71: 2113-2117, 1974.

19. Greenwood FC, Hunter WM and Glover JS: The preparation of I-131-labelled human growth hormone of high specific radioactivity. Biochem J 89: 114-123, 1963.

20. Patrick J and Lindstrom J: Autoimmune response to acetylcholine receptor. Science 180: 871-872, 1973.

21. Tindall RS, Kent M and Wells L: A rapid immunoadsorbent radioimmunoassay for anti-acetylcholine receptor antibody. J Immunol Methods 45: 1-14, 1981.

22. Hayashi M, Takaoka T, Manabe K, Yoshinaga J and Kida K: Comparison of antibody titer to human and rat acetylcholine receptor in myasthenia gravis. Brain Dev 17: 38-41, 1995.

23. Oda K, Goto I, Kuroiwa Y, Onoue K and Ito Y: Myasthenia gravis: antibodies to acetylcholine receptor with human and rat antigens. Neurology 30: 543-546, 1980.

24. Kordas G, Lagoumintzis G, Sideris S, Poulas K and Tzartos SJ: Direct proof of the in vivo pathogenic role of the AChR autoantibodies from myasthenia gravis patients. PLoS One 9: e108327, 2014.

25. Heyman B: Antibody feedback suppression: Towards a unifying concept? Immunol Lett 68: 41-45, 1999.

26. Heyman B: Feedback regulation by IgG antibodies. Immunol Lett 88: 157-161, 2003.

27. PLOS ONE Staff: Correction: Direct proof of the in vivo pathogenic role of the AChR autoantibodies from myasthenia gravis patients. PLoS One 10: e0117673, 2015.

28. Schürholz T, Kehne J, Gieselmann A and Neumann E: Functional reconstitution of the nicotinic acetylcholine receptor by CHAPS dialysis depends on the concentrations of salt, lipid, and protein. Biochemistry 31: 5067-5077, 1992.

29. Chang HW and Bock E: Factors influencing the stability of isolated acetylcholine receptor from Torpedo californica. Neurochem Int 2C: 269-280, 1980.

30. Tzartos SJ, Morel E, Efthimiadis A, Bustarret AF, D'Anglejan J, Drosos AA and Moutsopoulos HA: Fine antigenic specificities of antibodies in sera from patients with D-penicillamine-induced myasthenia gravis. Clin Exp Immunol 74: 80-86, 1988. 